\title{
Measurements of Atmospheric Concentrations of Reduced Sulphur Compounds in the All Saints Bay Area in Bahia, Brazil
}

\author{
L. S. S. NUNES ${ }^{1}$, T. M. TAVARES ${ }^{1}$, J. DIPPEL ${ }^{2}$ and W. JAESCHKE ${ }^{2}$ \\ ${ }^{1}$ LAQUAM - Laboratório de Química Analítica Ambiental, Instituto de Química, UFBA, Campus \\ Universitário de Ondina, salas 407/409 CEP 40170-290 Salvador, Bahia, Brazil, \\ e-mail:nunesls@hotmail.com \\ ${ }^{2} Z U F$ - Zentrum für Umweltforschung, Johann-Wolfgang-Goethe-Universität, Frankfurt, \\ Georg-Voigt-Straße 14, 60325 Frankfurt am Main, Germany
}

(Received: 26 November 2002; accepted: 1 July 2004)

\begin{abstract}
Atmospheric concentrations of several reduced sulphur compounds $\left(\mathrm{H}_{2} \mathrm{~S}, \mathrm{COS}, \mathrm{CH}_{3} \mathrm{SH}\right.$, $\mathrm{CH}_{3} \mathrm{SCH}_{3}, \mathrm{CS}_{2}$ ) originating from both natural and anthropogenic sources were measured at a number of locations in the All Saints Bay area and Reconcavo Baiano, Brazil. The volatile reduced sulphur compounds were collected by pre-concentration using cryo-tubes. Analysis of these compounds was carried out at a later date using gas chromatography with a flame photometric detector. In areas dominated by biogenic sources, the COS concentration varied between 0.5 and $1.0 \mathrm{ppbv}$, consistent with its normal global distribution in the atmosphere. Areas without direct industrial influence showed low atmospheric concentrations for all volatile sulphur compounds $\left(\leq 0.25 \mathrm{ppb}_{\mathrm{v}}\right)$. The anthropogenic influence of the Petrochemical Complex in Camaçari resulted in relatively high levels of some reduced sulphur compounds, such as $\mathrm{COS}\left(8 \mathrm{ppb}_{\mathrm{v}}\right), \mathrm{CH}_{3} \mathrm{SH}\left(1.50 \mathrm{ppb}_{\mathrm{v}}\right), \mathrm{H}_{2} \mathrm{~S}\left(1.35 \mathrm{ppb}_{\mathrm{v}}\right)$ and $\mathrm{CS}_{2}\left(0.3 \mathrm{ppb}_{\mathrm{v}}\right)$. In mangrove areas, the $\mathrm{H}_{2} \mathrm{~S}$ concentrations $\left(0.2 \mathrm{ppb}_{\mathrm{v}}\right)$ were almost twice as high as those in the air masses arriving from the Atlantic Ocean. The maximum $\mathrm{H}_{2} \mathrm{~S}$ concentrations were found in the industrial area of the Petrochemical Complex in Camaçari, but did not reach the limit of human perception $(0.14$ $\left.\mathrm{ppb}_{\mathrm{v}}\right)$ and rarely reached the typical recognizable smelling level $\left(0.40 \mathrm{ppb}_{\mathrm{v}}\right)$. Industrial emissions from the Landulfo Alves Refinery increased the COS, DMS and $\mathrm{CS}_{2}$ concentrations to 2.0, 0.55 and $0.2 \mathrm{ppb}_{\mathrm{v}}$, respectively.
\end{abstract}

Key words: anthropogenic sources, atmospheric concentrations, Brazil, mangrove areas, reduced sulphur compounds

\section{Introduction}

Reduced sulphur compounds (RSCs), such as $\mathrm{H}_{2} \mathrm{~S}, \mathrm{COS}, \mathrm{CH}_{3} \mathrm{SH}, \mathrm{CH}_{3} \mathrm{SCH}_{3}$, $\mathrm{CS}_{2}$, are released into the atmosphere from both biogenic sources (through the assimilatory and dissimilatory reduction of sulphate, volcanic activities) and anthropogenic sources, such as natural gas and petroleum exploitation, petroleum refining, pulp mills, biomass burning, etc. (Berresheim and Jaeschke, 1983; Andreae and Jaeschke, 1992; Bates et al., 1992; Cullis and Hirscher, 1980; Fagá 
et al., 1985; Galloway et al., 1985). These emissions are ultimately responsible for changing local and/or global climate. DMS (originated from biogenic production by marine phytoplankton) is the only natural reduced sulphur gas responsible for global climate through a multistep and complex feedback mechanism, which includes the formation of cloud condensation nuclei (CCN) over the oceans. This affects indirectly the albedo of marine clouds (Andrea et al., 1995; Charlson et al., 1987; Davison and Allen, 1994; Kangas et al., 1984). Most RSCs are photooxidized in the atmosphere and transferred to other regions. COS (through the atmospheric photo-oxidation of $\mathrm{CS}_{2}$ ) is the most abundant atmospheric sulphur gas in the remote troposphere, with an average concentration of aproximately $500 \mathrm{ppt}_{\mathrm{v}}$. Because of its low chemical reactivity and correspondingly long residence time (of the order of one year), it is the only sulphur compound (except during $\mathrm{SO}_{2}$ injections during large volcanic eruptions) that can diffuse into the stratosphere. The imput of COS might play a role in the formation and maintenance of the stratospheric sulphate layer during volcanically quiescent periods due to its efficient photolysis and conversion to sulphuric acid in the atmosphere (Andreae and Jaeschke, 1992; Berresheim et al., 1995; Berresheim and Vulcan, 1992). Most RSCs are toxic and, depending on their concentrations, may cause damage to the environment and the local human population (Martilla et al., 1995; HSDB, 1994).

Despite recent improvements in measurement techniques, the actual volume of data on RSCs in Latin America are limited. So far, only a few measurements have been carried out in the Southern Hemisphere, of which none were carried out in coastal sites in South America (Warneck, 1988). The highly industrialized area of Cubatão, São Paulo, Brazil is the only area in which an investigation of this kind has been carried out in South America (Jaeschke et al., 1994; Dippell and Jaeschke, 1996). The aim of this study was to determine the atmospheric RSCs levels dominated by natural emissions (maritime and mangrove areas) and intensified by industrial emissions.

\section{Experimental}

\subsection{LOCATION AND CLIMATE}

Reconcavo Baiano is a geographic region comprising the All Saints Bay area (1100 $\mathrm{km}^{2}$, in Portuguese: Baia de Todos os Santos) and the adjacent countryside, totalling $16,300 \mathrm{~km}^{2}$ between $12^{\circ} \mathrm{S}$ and $13^{\circ} 15^{\prime} \mathrm{S}$ and $38^{\circ} \mathrm{W}$ and $39^{\circ} 30^{\prime} \mathrm{W}$. In recent decades, this area has experienced one of the fastest industrial growths in the country. Present activities include a petroleum refinery of approximately 215,000 barrel/day (data from 2001), several metallurgical plants, a pulp mill and the largest petrochemical complex of the Southern Hemisphere (Figure 1). The city of Salvador, which has approximately three million inhabitants, is the capital of the Federal State of Bahia and is located on the tip of the peninsula enclosing the All Saints Bay area. The pattern of land occupation and distribution is uneven; the prevailing winds blow 


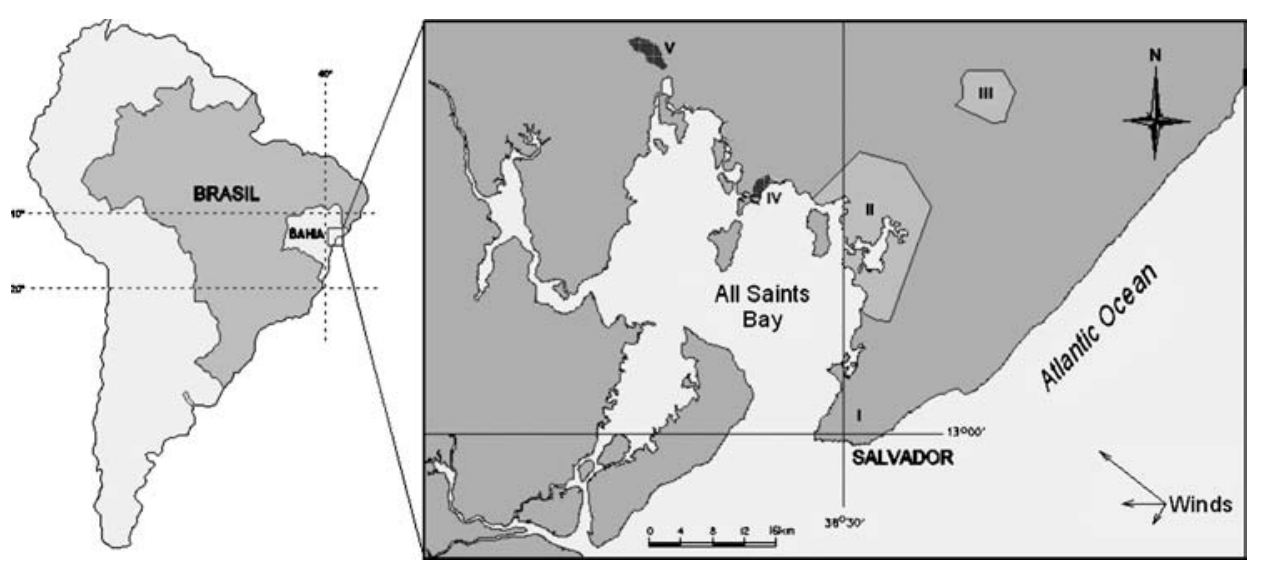

Figure 1. Map of the study area: (1) Salvador, (II) CIA: Aratu Industrial Center, (III) Petrochemical Complex, (IV) Refinery, (V) Paraguaçu River.

from the Atlantic Ocean for two-thirds of the time, with a monthly average velocity ranging between 2.0 and $4.4 \mathrm{~m} \mathrm{~s}^{-1}$ (no wind for $14 \%$ of the time). Here air masses are available for the determination of background levels and natural emissions.

\subsubsection{Measurement Locations}

To perform detailed studies of RSC levels in the Reconcavo Baiano two specific areas were selected: the area of the Petrochemical Complex of Camaçari and the beaches around the All Saints Bay area. Most of the sites chosen for the anthropogenic campaign in 1995 belong to the Petrochemical Complex of Camaçari and are potentially dominated by RSCs from industrial sources. The characteristics of each sites are shown in Table III. The sampling locations at Arembepe and Praia do Forte are coastal locations, distant from industrial sources with pollutant concentrations as near as possible to background.

The locations around the Bay, which were investigated in the campaign for natural emissions of RSCs in 1996, are presented in Figure 7. Only the site of Madre de Deus is expected to be influenced by anthropogenic emission from the refinery. All the others are influenced by biogenic emissions from mangrove areas, where we would not expect high concentrations of RSCs. Once again, the coastline location of Arembepe was chosen to represent background conditions.

\subsection{ANALYTICAL METHOD AND SAMPLING}

Since the sampling methods and the analytical proceedings have already been described in detail (Jaeschke et al., 1994; Haunold et al., 1992), only a brief outline is presented in this text. The volatile sulphur compounds were collected in cryo-tubes and analyzed using gas chromatography with a flame photometric detector. Samples 
were taken using cryogenic enrichment of air at the measuring sites. Sampling was conducted with the aid of glass tubes (containing cotton wool) immersed in liquid argon. Oxidants were removed prior to the cryogenic trapping using a cotton wool scrubber. Mass flow controllers or differential pressure sensors assured a constant flow rate of $150 \mathrm{~mL} \mathrm{~min}{ }^{-1}$. The differential pressure sensors, the pump, a power supply (battery), the scrubber and the connecting tubes were pre-installed in portable cases. Pre-installation facilitates the handling and accelerates mounting and dismounting of the equipment in the field. For subsequent analysis, gas chromatography with a flame photometric detector was applied. The sulphur compounds were desorbed in a two-step process. Firstly, $\mathrm{CO}_{2}, \mathrm{H}_{2} \mathrm{~S}$ and $\mathrm{COS}$ were desorbed at $-78^{\circ} \mathrm{C}$ (dry ice/ethanol), and the compounds were then separated at $5^{\circ} \mathrm{C}$ column temperature. After a second desorption at room temperature $\left(25^{\circ} \mathrm{C}\right)$, the remaining sulphur compounds $\left(\mathrm{CH}_{3} \mathrm{SH}, \mathrm{CH}_{3} \mathrm{SCH}_{3}\right.$ and $\left.\mathrm{CS}_{2}\right)$ were separated at $60{ }^{\circ} \mathrm{C}$ column temperature. The temperature of the analytical column was controlled by Peltier elements. The sampling efficiency varied between 94 and $96 \%$ for all compounds and was valid for sampling flow rates between 100 and $200 \mathrm{~mL}$ $\mathrm{min}^{-1}$. Calibration of the compounds of interest was accomplished while in their gaseous phase, using permeation tubes kept in a warm block $\left(30.0 \pm 0.1{ }^{\circ} \mathrm{C}\right)$ and diluted with $\mathrm{N}_{2}$ gas. An upper limit of the overall analytical precision was calculated to be $11 \%$ for $\mathrm{H}_{2} \mathrm{~S}$ and $5 \%$ for COS. The detection limit of this methodology varies between 2.8 and $5.8 \mathrm{pmol} / \mathrm{sampling}$, while the quantification limit varies between 22.5 and 46.8 pptv in 9L of air. Four or five air samples were taken during 15-20 min (polluted areas) to 30-45 min (non-polluted environments) at each site.

A portable meteorological station (Lambrecht) was used to acquire and store the local atmospheric data, such as wind speed and direction, temperature and relative humidity.

\section{Results and Discussion}

\subsection{BACKGROUND LEVELS}

Two measurement sites (Praia do Forte and Arembepe), which are $43 \mathrm{~km}$ apart, are highly influenced by the Atlantic Ocean's clean maritime air masses. The investigation proved the ocean's contribution to low atmospheric concentration of RSCs. DMS and COS are expected to be detected under such environmental conditions. DMS is produced from biological activity of phytoplankton and zooplankton in maritime surfaces (Davison et al., 1996; Nguyen et al., 1992; Tarrasón et al., 1995; Matrai et al., 1993). COS originates from a relatively large oceanic source and has a low reactivity and a long residence time in the atmosphere with an average concentration of 500 pptv (Berresheim et al., 1995; Berresheim and Jaeschke, 1983). These sites were used as background stations, alternately, for measurements in both biogenic and anthropogenic campaigns (air masses). The third location, in Ondina (approx. 45 masl), is an important measurement site since it is surrounded by some 
remains of the original Atlantic Rain Forest. It is one of the Salvador's cleanest locations, despite its vicinity to the city centre, while the out-of-town sites of Praia do Forte and Arembepe are influenced by RSCs input from the maritime environment only.

Figures 2(a), (b) and (c) show backward trajectories for the Ondina, Praia do Forte and Arembepe stations provide by NOAA HYSPLIT MODEL. The figures indicate clearly that the air masses reaching these sites originate from the Atlantic Ocean.

NOAA HYSPLIT MODEL

Backward trajectory ending at 10 UTC 02 May 95 CDC1 Meteorological Data

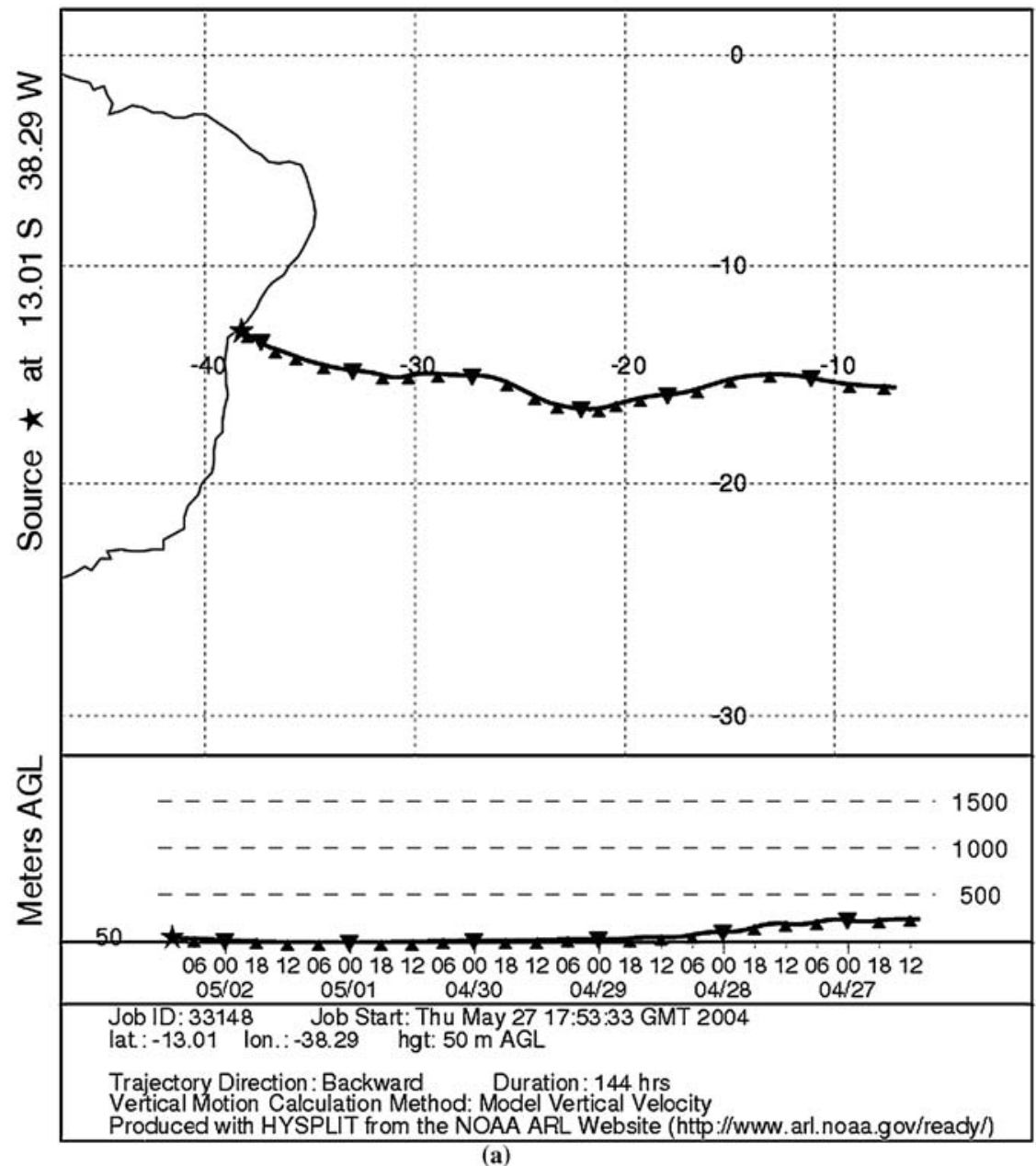

Figure 2. Backward trajectories: (a) Ondina, (b) Praia do Forte and (c) Arembepe. 


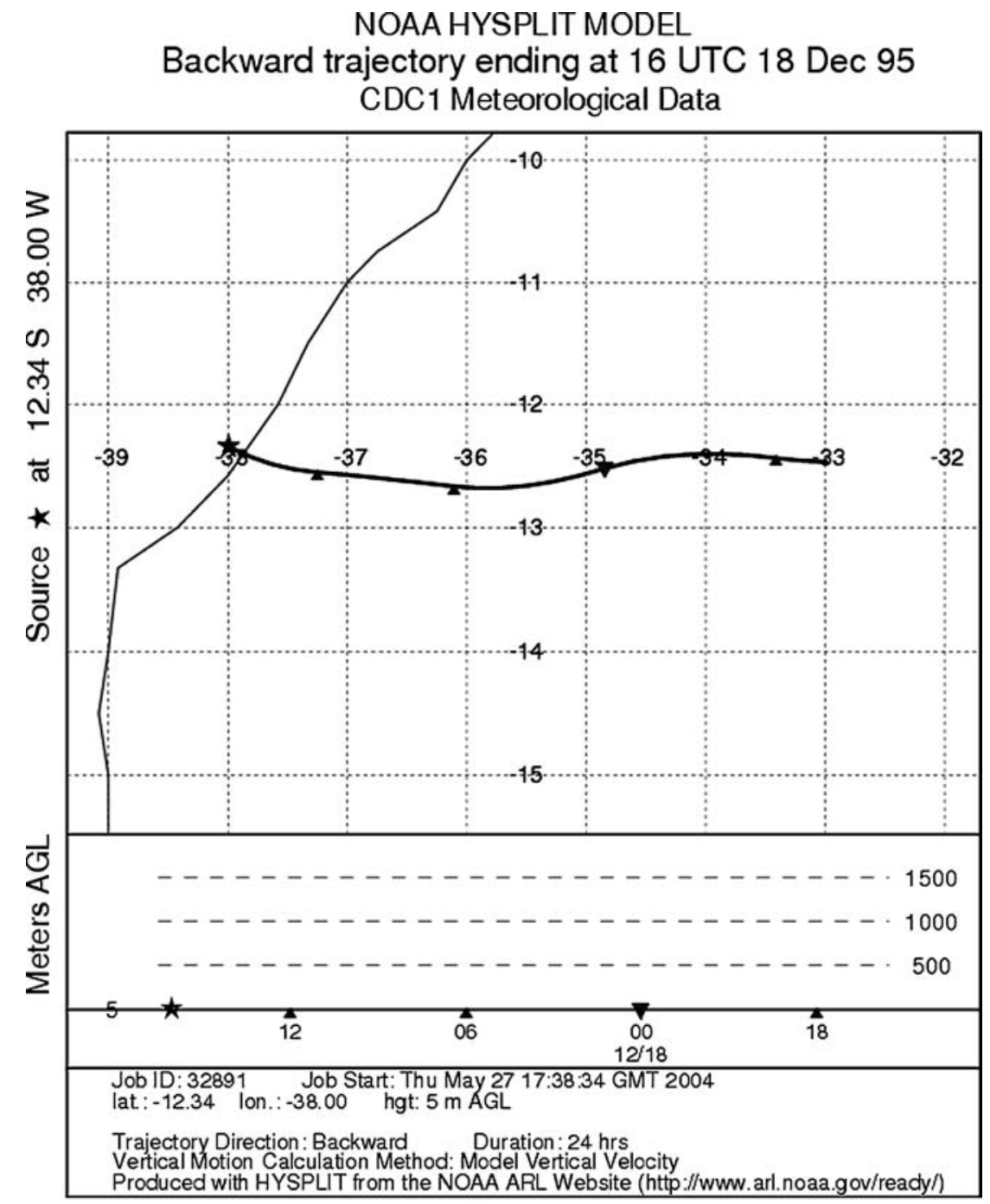

(b)

Figure 2. (Continued on next page.)

COS was detected in all samples taken from these three sites. DMS was found in 8 samples in Ondina, 17 samples in Praia do Forte and 7 samples in Arembepe. The average DMS concentrations at the sites were $1.5 \mathrm{nmol} \mathrm{m}^{-3}\left(33 \mathrm{ppt}_{\mathrm{v}}\right), 2.1 \mathrm{nmol} \mathrm{m}^{-3}$ $\left(47 \mathrm{ppt}_{\mathrm{v}}\right)$ and $2.4 \mathrm{nmol} \mathrm{m}^{-3}\left(53 \mathrm{ppt}_{\mathrm{v}}\right)$, respectively. These measurements do not differ significantly. $\mathrm{H}_{2} \mathrm{~S}$ was detected in only four samples in Ondina, reaching a maximum concentration of about $18 \mathrm{nmol} \mathrm{m}^{-3}$ (400 ppt). $\mathrm{H}_{2} \mathrm{~S}$ was also detected in one sample in Praia do Forte and in four samples in Arembepe. $\mathrm{CS}_{2}$ was detected in only three samples in Arembepe. Table I shows the RSC atmospheric concentrations in Ondina, Praia do Forte and Arembepe during the sampling periods in 1995 and 1996. 


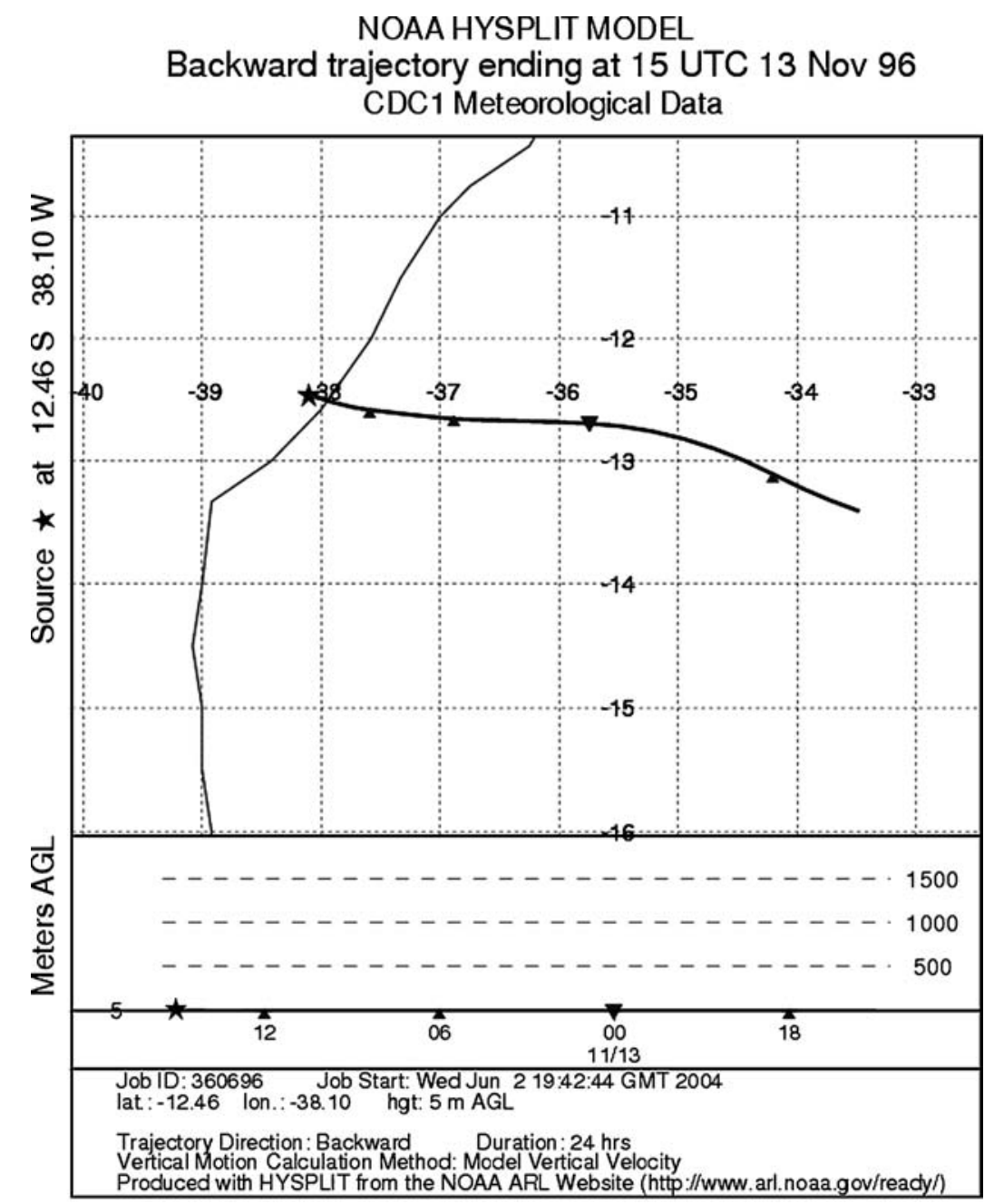

(c)

Figure 2. (Continued).

As can be seen in Table I, the $\mathrm{OH}^{\bullet}$ concentration increases during the day (mainly in the afternoon) and consumption of $\mathrm{H}_{2} \mathrm{~S}$ occurs simultaneously. In fact, in Ondina, Praia do Forte and Arembepe, between 10 am and 4 pm, almost all the hydrogen sulphide in the atmosphere is consumed by $\mathrm{OH}^{\bullet}$ and/or diluted by the sea breeze. After midnight, between 2 am and 4 a.m. and 6 am and 8 a.m., there is a reduction in the $\mathrm{OH}^{\bullet}$ concentration when winds tend to subside (during the doldrums period). Consequently, an increase in $\mathrm{H}_{2} \mathrm{~S}$ concentration in the atmosphere is detected (18 nmol m${ }^{-3}=400$ ppt $_{v}$, from 7:00 a.m. to 9:00 a.m.). The phenomenon observed in Ondina may have been caused by local traffic, which intensifies during the morning rush-hour, or by the decomposition of garbage and an inadequate sewage system in 
Table I. Atmospheric concentrations of reduced sulphur compounds and their standard deviations in the background stations of Ondina, Praia do Forte and Arembepe in 1995/96

\begin{tabular}{|c|c|c|c|c|c|c|c|c|}
\hline \multirow{2}{*}{$\begin{array}{l}\text { Site } \\
\text { locations }\end{array}$} & \multirow{2}{*}{\multicolumn{2}{|c|}{$\begin{array}{l}\text { Date } \\
\text { (h) }\end{array}$}} & \multirow[b]{2}{*}{ Time } & \multirow{2}{*}{$\begin{array}{l}\text { No. of } \\
\text { samples }\end{array}$} & \multicolumn{4}{|c|}{$\begin{array}{l}\text { Average concentrations }\left(\mathrm{nmol} \mathrm{m}^{-3}\right) \\
\text { with standard deviations }\end{array}$} \\
\hline & & & & & $\mathrm{H}_{2} \mathrm{~S}$ & $\mathrm{CS}_{2}$ & DMS & $\mathrm{COS}$ \\
\hline \multirow{7}{*}{ Ondina } & April, & $26 / 95$ & $16-17$ & 3 & - & - & - & $26.6 \pm 2.6$ \\
\hline & April, & $27 / 95$ & $15-18$ & 4 & - & - & $1.8 \pm 0.8$ & $22.5 \pm 1.7$ \\
\hline & April, & $28 / 95$ & $10-18$ & 5 & - & - & - & $22.2 \pm 1.9$ \\
\hline & April, & 29/95 & $10-13$ & 3 & - & - & - & $20.8 \pm 1.0$ \\
\hline & April, & $30 / 95$ & $08-13$ & 2 & $15 \pm 2.3$ & - & $0.9 \pm 0.2$ & $23.5 \pm 1.7$ \\
\hline & May, & $02 / 95$ & 06-09 & 2 & $18 \pm 2.5$ & - & $1.7 \pm 0.3$ & $25.4 \pm 1.3$ \\
\hline & May, & $03 / 95$ & $10-14$ & 4 & - & - & $2.0 \pm 0.2$ & $24.7 \pm 1.1$ \\
\hline Praia & May, & $04 / 95$ & $10-13$ & 3 & - & - & $2.2 \pm 0.7$ & $21.7 \pm 0.7$ \\
\hline Do & May, & $05 / 95$ & $10-13$ & 3 & - & - & $1.8 \pm 0.3$ & $21.8 \pm 0.4$ \\
\hline \multirow[t]{2}{*}{ Forte } & May, & $07 / 95$ & 05-09 & 4 & - & - & $2.1 \pm 0.8$ & $22.5 \pm 3.2$ \\
\hline & Dec, & $18 / 95$ & $13-16$ & 3 & 1.9 & - & $2.3 \pm 0.3$ & $35.3 \pm 1.2$ \\
\hline \multirow[t]{2}{*}{ Arembepe } & Dec, & $18 / 95$ & $12-16$ & 4 & 2.7 & - & $3.5 \pm 0.9$ & $33.4 \pm 2.2$ \\
\hline & Nov, & $13 / 96$ & 09-13 & 5 & $3.0 \pm 0.8$ & $3.0 \pm 0.7$ & $1.2 \pm 0.3$ & $21.4 \pm 1.6$ \\
\hline
\end{tabular}

the area. After this short period, winds from the East intensify and are accompanied by a typical RSC smell. This phenomenon observed in Ondina is also recorded in another study (Nunes, 1995). Praia do Forte was chosen as a background site for the sampling campaign of November 1995, while Arembepe was the background site for the studies of anthropogenic and biogenic influence of RSCs in the All Saints Bay area in 1995 and 1996.

To validate our assumption about the chosen background sites, Table II presents some maritime sites and corresponding atmospheric RSC concentrations.

Despite the high $\mathrm{H}_{2} \mathrm{~S}$ concentrations found in Ondina and explained above, the atmospheric concentrations of DMS and COS presented in Table I agree with the results shown in Table II.

\subsection{ANTHROPOGENIC LEVELS}

Qualitative results are summarized in Table III and a more detailed representation including quantitative data can be observed in Figure 3.

During this campaign, $24 \mathrm{~h}$ semi-continuous measurements and night-timesampling were carried out in the city of Camaçari to obtain a better understanding of the diurnal variation of RSC concentrations (Figure 4). In addition to the sampling of RSCs, meteorological parameters were recorded using a mobile meteorological station. 
Table II. Atmospheric concentrations of RSC in some maritime sites by different authors

\begin{tabular}{|c|c|c|c|c|}
\hline \multirow[b]{2}{*}{ Compound } & \multirow[b]{2}{*}{ Site } & \multicolumn{2}{|c|}{ Concentration } & \multirow[t]{2}{*}{ Reference } \\
\hline & & $\mathrm{ppt}_{\mathrm{v}}$ & $\mathrm{nmol} \mathrm{m}^{-3}$ & \\
\hline \multirow[t]{5}{*}{ DMS } & Tropical South Atlantic & $37-60$ & & Andreae et al., 1995 \\
\hline & $\begin{array}{l}\text { Marine surface layer } \\
\quad \text { (Atlantic Ocean) }\end{array}$ & 80 & 3.7 & Berresheim, 1995 \\
\hline & $\begin{array}{l}\text { Marine surface layer } \\
\text { (Pacific Ocean) }\end{array}$ & 110 & 5.0 & Berresheim, 1995 \\
\hline & $\begin{array}{l}\text { Boundary layer } \\
\text { (North and S. Atlantic) }\end{array}$ & $34-118$ & $1.6-5.4$ & $\begin{array}{l}\text { Cooper and Saltzman, } \\
1993\end{array}$ \\
\hline & $\begin{array}{l}\text { Mixture layer } \\
\quad \text { (Tropical Atlantic) }\end{array}$ & $20-100$ & $0.9-4.5$ & Andreae et al., 1993 \\
\hline \multirow[t]{2}{*}{$\operatorname{COS}$} & $\begin{array}{l}\text { Marine surface layer } \\
\text { (All Oceans) }\end{array}$ & 500 & 22.5 & Berresheim, 1995 \\
\hline & $\begin{array}{l}\text { Indian Ocean } \\
\quad \text { (Amsterdam Island) }\end{array}$ & 510 & 23 & $\begin{array}{l}\text { Mihalopoulos et al., } \\
\quad 1992\end{array}$ \\
\hline \multirow[t]{2}{*}{$\mathrm{H}_{2} \mathrm{~S}$} & $\begin{array}{l}\text { Marine surface layer } \\
\text { (Atlantic Ocean) }\end{array}$ & 7 & 0.3 & Berresheim, 1995 \\
\hline & $\begin{array}{l}\text { Maritime air } \\
\quad \text { (Tropical Atlantic) }\end{array}$ & $5-10$ & $0.2-0.5$ & Andreae et al., 1993 \\
\hline
\end{tabular}

During the entire sampling period at the Petrochemical Complex of Camaçari (Nov/28 - Dec/14, 1995), the wind blew predominantly from the Atlantic Ocean $\left(30-150^{\circ} \mathrm{C}\right)$ with a velocity up to $5.5 \mathrm{~m} \mathrm{~s}^{-1}$. In this area the wind directions vary frequently, but along the coast line of Salvador there is a strong sea breeze during the daytime. Consequently, the industrial emissions are effectively diluted so that high concentrations of RSCs were not measured in the direct vicinity of an emission source. In fact, the environmental concentrations showed values that were lower than or just above background for almost all compounds in all locations during the daytime (Figure 3: COFIC, BA-093/Lamarão do Passé, Gravatá, BACELL and Dias d'Ávila), with only two exceptions. First, the sampling device was coincidentally placed above a shaft of an industrial wastewater channel, resulting in peak concentrations for COS, $8 \mathrm{ppb}_{\mathrm{v}}$; $\mathrm{CH}_{3} \mathrm{SH}, 1.50 \mathrm{ppb}_{\mathrm{v}}$ and $\mathrm{H}_{2} \mathrm{~S}, 1.35 \mathrm{ppb}_{\mathrm{v}}$ (Figure 3: CETREL). Second, the sampling device was placed in front of the RHODIA industrial complex during a purge process reaching a $\mathrm{CH}_{3} \mathrm{SH}$ concentration of $3.1 \mathrm{ppb}_{\mathrm{v}}$. This measurement was carried out in Oct, 94, about one year before the present campaign.

During the night, the vertical mixing of the atmosphere and its oxidation capacity are relatively low and the RSCs are expected to accumulate at ground level. Most results confirmed this assumption, especially for the short-lived compounds $\mathrm{CH}_{3} \mathrm{SH}, \mathrm{H}_{2} \mathrm{~S}$ and DMS, which displayed maximum concentrations at night. Peak concentrations were $1.50 \mathrm{ppb}_{\mathrm{v}}$ for $\mathrm{H}_{2} \mathrm{~S}$ (Camaçari) and $0.30 \mathrm{ppb}_{\mathrm{v}}$ for $\mathrm{CH}_{3} \mathrm{SH}$ 
Table III. Reduced sulphur compounds detected in the sampling locations influenced by industrial sources in 1995

\begin{tabular}{|c|c|c|c|c|c|}
\hline Sampling location & $\begin{array}{l}\text { Site } \\
\text { characteristics }\end{array}$ & $\begin{array}{l}\text { Date } \\
(1995)\end{array}$ & $\begin{array}{l}\text { Period } \\
\text { (h) }\end{array}$ & $\begin{array}{l}\text { No. of } \\
\text { samples }\end{array}$ & $\begin{array}{l}\text { RSC } \\
\text { detected }^{\mathrm{a}}\end{array}$ \\
\hline Rótula do COFIC (1) & $\begin{array}{l}\text { Downwind } \\
\text { petrochemical } \\
\text { transformation } \\
\text { industry }\end{array}$ & Nov/28 & $10-15$ & 09 & $\begin{array}{l}\operatorname{COS}(9), \mathrm{CS}_{2} \\
\quad(2)\end{array}$ \\
\hline \multirow[t]{2}{*}{ [2pt] Saída da Rhodia (2) } & $\begin{array}{l}\text { Downwind } \\
\text { industrial } \\
\text { complex and } \\
\text { metionina } \\
\text { factory }\end{array}$ & Nov/28 & $14-16$ & 05 & $\begin{array}{r}\operatorname{COS}(5), \mathrm{H}_{2} \mathrm{~S} \\
(1), \mathrm{CS}_{2}(1)\end{array}$ \\
\hline & & $\mathrm{Feb} / 04$ & $12-14$ & 05 & $\begin{array}{l}\mathrm{COS}(5), \\
\mathrm{CH}_{3} \mathrm{SH}(1), \\
\mathrm{CS}_{2}(1)\end{array}$ \\
\hline Lamarão do Passe (3) & $\begin{array}{l}\text { City downwind } \\
\text { industrial } \\
\text { complex }\end{array}$ & Dec/01 & $09-14$ & 05 & $\begin{array}{l}\mathrm{COS}(5), \mathrm{H}_{2} \mathrm{~S} \\
(4), \mathrm{CS}_{2}(1)\end{array}$ \\
\hline BA-093 (4) & $\begin{array}{l}\text { Road downwind } \\
\text { Cellulose and } \\
\text { paper industry }\end{array}$ & & & 04 & $\begin{array}{c}\mathrm{COS}(4), \mathrm{H}_{2} \mathrm{~S} \\
(2), \mathrm{CS}_{2}(4)\end{array}$ \\
\hline Gravatá(Camaçari) (5) & $\begin{array}{l}\text { City in the vicinity } \\
\text { of the industrial } \\
\text { complex }\end{array}$ & Dec/03-04 & $20-18$ & 17 & $\begin{array}{l}\mathrm{COS}(17), \\
\mathrm{CH}_{3} \mathrm{SH}(4), \\
\mathrm{H}_{2} \mathrm{~S}(8), \mathrm{DMS} \\
(2)\end{array}$ \\
\hline [2pt] BACELL (6) & $\begin{array}{l}\text { Cellulose and } \\
\text { paper industry }\end{array}$ & Dec/06 & $02-05$ & 05 & $\begin{array}{l}\mathrm{COS}(5), \\
\mathrm{CH}_{3} \mathrm{SH}(1), \\
\operatorname{DMS}(3)\end{array}$ \\
\hline CETREL (7) & $\begin{array}{l}\text { Industrial effluents } \\
\text { treatment station }\end{array}$ & Dec/12 & $14-18$ & 06 & $\begin{array}{l}\mathrm{COS}(6), \\
\mathrm{CH}_{3} \mathrm{SH}(1), \\
\mathrm{H}_{2} \mathrm{~S}(4), \mathrm{DMS} \\
(1), \mathrm{CS}_{2}(1)\end{array}$ \\
\hline Dias d'Ávila (8) & $\begin{array}{l}\text { City in the vicinity } \\
\text { of the industrial } \\
\text { complex }\end{array}$ & Dec/13-14 & $22-07$ & 10 & $\begin{array}{c}\text { COS (10), DMS } \\
(8), \mathrm{CS}_{2}(6)\end{array}$ \\
\hline Arembepe (9) & $\begin{array}{l}\text { Background } \\
\text { coastal site }\end{array}$ & Dec/18 & $12-16$ & 04 & $\begin{array}{l}\mathrm{COS}(4), \mathrm{H}_{2} \mathrm{~S} \\
(1), \mathrm{DMS}(4)\end{array}$ \\
\hline Praia do Forte (10) & $\begin{array}{l}\text { Background } \\
\text { coastal site }\end{array}$ & & & 03 & $\begin{array}{l}\operatorname{COS}(3), \mathrm{H}_{2} \mathrm{~S} \\
\quad(1), \operatorname{DMS}(3)\end{array}$ \\
\hline Ciba-Geigy (11) & $\begin{array}{l}\text { Mercaptan } \\
\text { emission } \\
\text { industry }\end{array}$ & Oct/94 & $10-11$ & 01 & $\begin{array}{r}\operatorname{COS}(1), \mathrm{H}_{2} \mathrm{~S} \\
(1), \mathrm{CS}_{2}(1)\end{array}$ \\
\hline
\end{tabular}

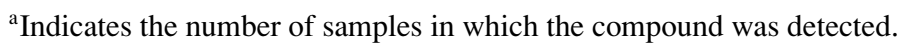




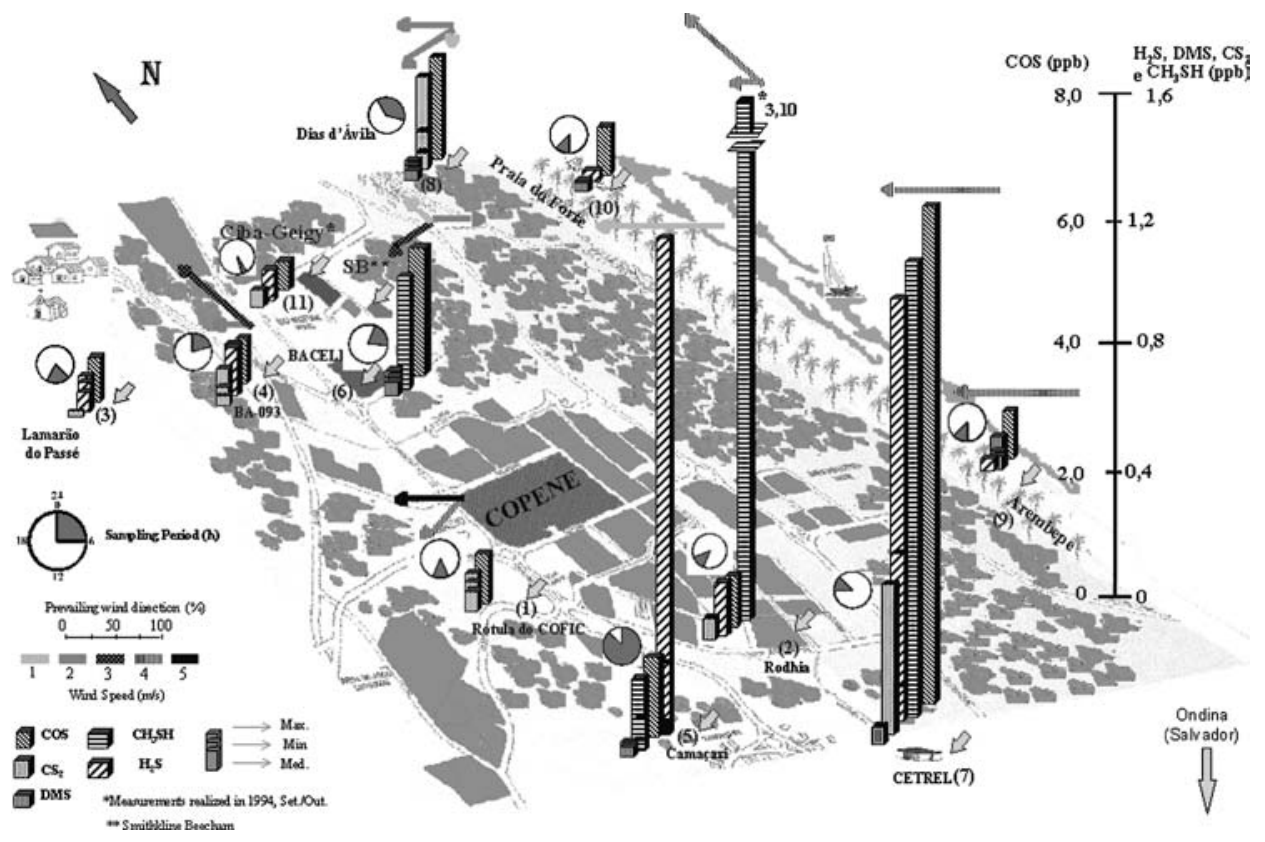

Figure 3. Measurements of reduced sulphur compounds downwind of industrial activities at the Petrochemical Complex of Camaçari, Nov/Dec 1995.

(Camaçari and BACELL). Maximum night-time concentrations for COS were 1.80 and $1.50 \mathrm{ppb}_{\mathrm{v}}$ (BACELL, Dias d'Ávila) and for $\mathrm{CS}_{2}, 0.30 \mathrm{ppb}_{\mathrm{v}}$ (Dias d'Ávila). DMS was present in most night-time samples and showed little variation, hardly exceeding $0.10 \mathrm{ppb}_{\mathrm{v}}$ (Gravatá, BACELL and Dias d'Ávila).

In only one case (resulting from 24-h sampling in Camaçari) an increase of COS concentration during the daytime was found, and it seems likely that this occured because the sampling site was downwind of a station treating industrial effluents, which was only operational during daytime. All other compounds dropped to low concentrations $\left(\mathrm{H}_{2} \mathrm{~S}\right)$ or even below their quantification limit $\left(\mathrm{CH}_{3} \mathrm{SH}\right.$ and DMS; Figure 4) since they are photo-oxidised by $\mathrm{OH}^{\bullet}$ radicals.

Marttila et al., 1995 have determined the total reduced sulphur compounds in the air $\left(\mathrm{H}_{2} \mathrm{~S}, \mathrm{CH}_{3} \mathrm{SH}, \mathrm{CH}_{3} \mathrm{SCH}_{3}\right.$ and $\left.\mathrm{CH}_{3} \mathrm{SSCH}_{3}\right)$ in the vicinity of a pulp mill located in southeast Finland. The results of this study and those from our investigation in Brazil are presented in Table IV.

Table IV shows that the atmospheric concentrations of TRS in the industrial area in Bahia, Brazil correspond to the 'medium' exposure reference of those determined in Finland. Nevertheless, the PCC is much bigger and formed by several industries including a pull mill (BACELL), which emits RSCs to the atmosphere.

Simultaneous sampling downwind of the Petrochemical Complex (PCC) revealed decreasing concentrations of $\mathrm{CS}_{2}$ with increasing distance from this emission 
Table IV. Atmospheric total reduced sulphur (TRS) compound concentrations in vicinity of a pulp mill in Finland by Marttila et al. (1995), and in Petrochemical Complex of Camaçari (PCC) in Bahia, Brazil

\begin{tabular}{ll}
\hline Exposure reference & TRS mean concentration $\left(\mu \mathrm{g} \mathrm{m}^{-3}\right)$ \\
\hline Daily & $<10$ \\
Medium & $11-14$ \\
High & $44-82$ \\
Monthly & $3-19$ \\
Our study. & $<17$ \\
\hline
\end{tabular}
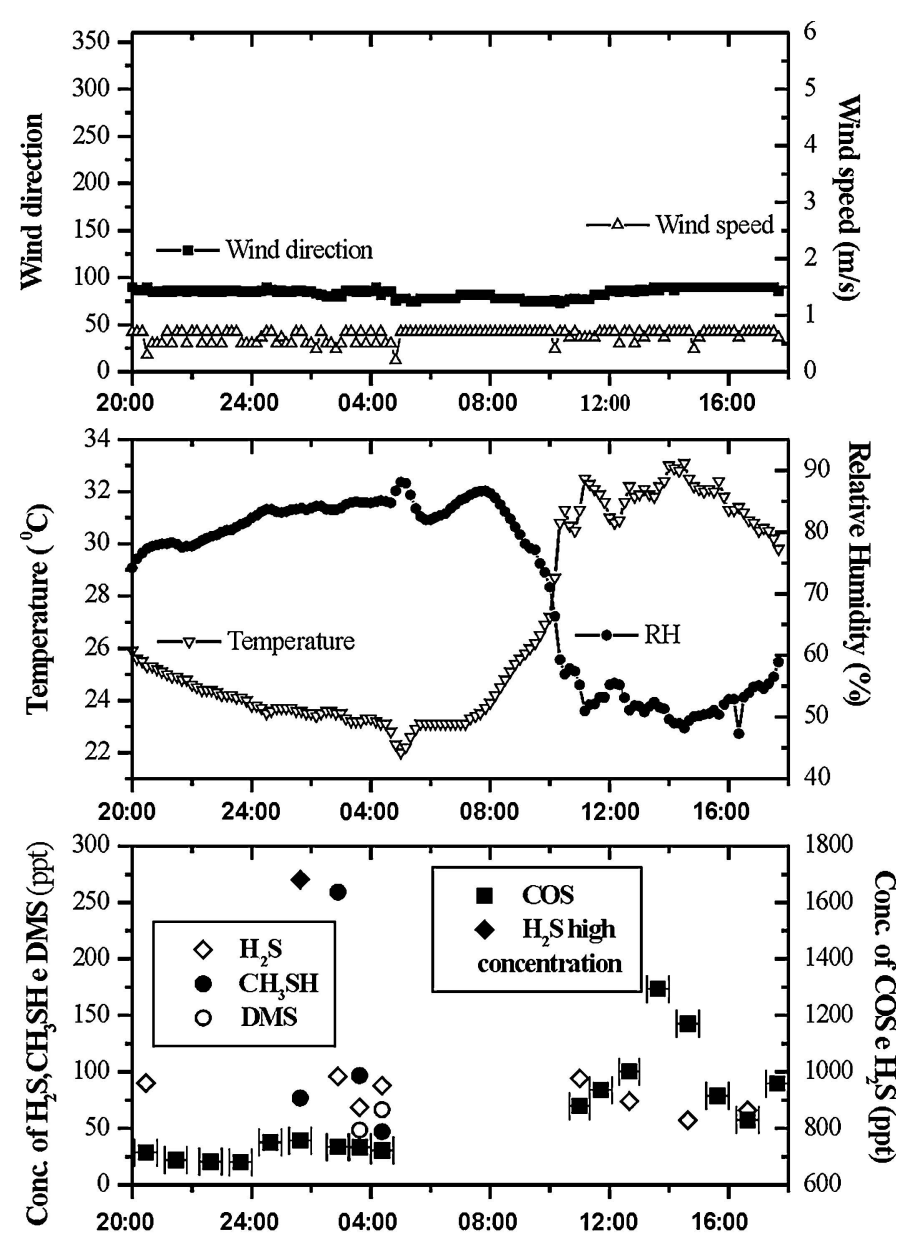

Dec/95 Time(h)

Figure 4. Atmospheric concentrations of RSC and meteorological data in Camaçari, Dec 1995. 


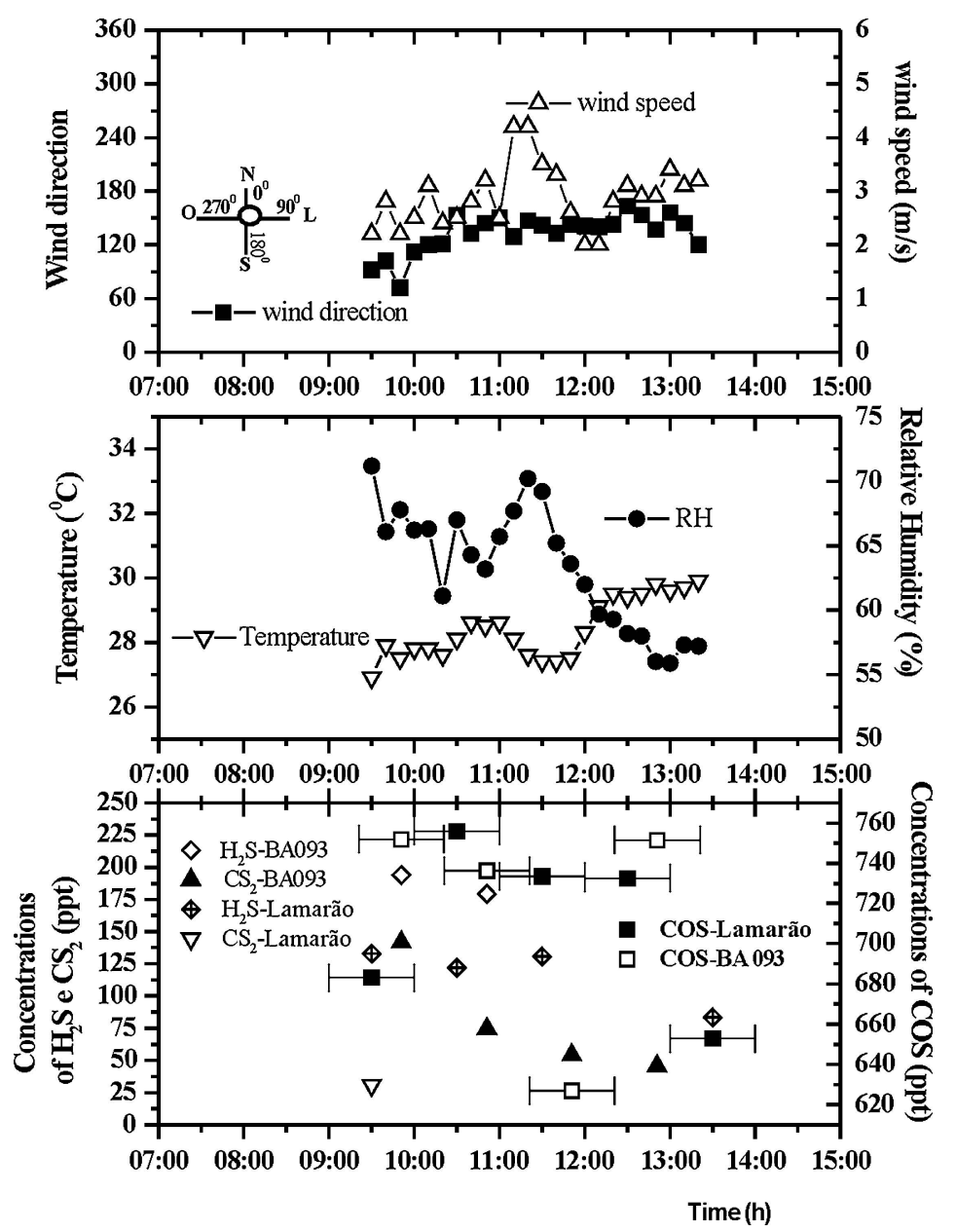

Figure 5. Simultaneous air sampling of RSC and meteorological data downwind of the Petrochemical Complex, Dec 1995.

source, whilst $\mathrm{COS}$ and $\mathrm{H}_{2} \mathrm{~S}$ values showed no clear trend. At the less distant locations from the $\mathrm{PCC}$ (BA-093) $\mathrm{H}_{2} \mathrm{~S}$ concentrations were higher initially, but dropped below the detection limit after two hours. At the more distant locations (Lamarão do Passé) a decreasing concentration was observed, but the values remained above the detection limit (Figure 5). Table V shows the variation of RSC concentrations with distance of the sites from the source.

Collection of representative samples close to industrial emission sources (such as Rhodia) often encountered problems with positioning of equipment due to the steadily changing wind directions. Hence, in December 1995 a multi-directional scattering of the pollutants occurred, which contributed to detection of extremely low values of the environmental RSC concentrations. Earlier, in October 1994, the same team of scientists encountered constant wind direction, which caused a 
Table V. RSC concentrations in sites BA-093 and Lamarão do Passé consistent with their sampling distance from the Petrochemical Complex of Camaçari (PCC)

\begin{tabular}{lcccccc}
\hline Period (h) & \multicolumn{6}{c}{ Average concentrations (ppt $)$} \\
\hline \multicolumn{5}{c}{ BA -093} & $(3.5 \mathrm{~km}$ from the source) & Lamarão do Passé (8 km from the source) \\
\hline & $\mathrm{H}_{2} \mathrm{~S}$ & $\mathrm{CS}_{2}$ & $\mathrm{COS}$ & $\mathrm{H}_{2} \mathrm{~S}$ & $\mathrm{CS}_{2}$ & $\mathrm{COS}$ \\
\hline $09: 30-09: 51$ & 190 & 140 & 750 & 130 & 31 & 680 \\
$10: 30-10: 51$ & 180 & 75 & 740 & 120 & - & 760 \\
$11: 30-11: 51$ & - & 54 & 630 & 130 & - & 730 \\
$12: 30-12: 51$ & - & 46 & 750 & - & - & 730 \\
\hline
\end{tabular}

Table VI. Atmospheric concentrations of RSC in

Cubatão, São Paulo from Jaeschke et al., 1994

\begin{tabular}{lll}
\hline Compound & \multicolumn{2}{c}{ Concentration } \\
\hline & $\mathrm{nmol} \mathrm{m}^{-3}$ & $\mathrm{ppb}_{\mathrm{v}}$ \\
\cline { 2 - 3 } & $30-100$ & $0.67-2.24$ \\
$\mathrm{H}_{2} \mathrm{~S}$ & $40-220$ & $0.90-4.93$ \\
$\mathrm{COS}$ & $60-170$ & $1.34-3.81$ \\
$\mathrm{CS}_{2}$ & \\
\hline
\end{tabular}

dispersion of the pollutants in one defined direction. These data also showed low atmospheric concentrations for $\mathrm{H}_{2} \mathrm{~S}\left(100 \mathrm{ppt}_{\mathrm{v}}\right)$ and $\mathrm{CS}_{2}\left(40 \mathrm{ppt}_{\mathrm{v}}\right)$.

Results from simultaneous sampling at the background stations Arembepe and Praia do Forte in December 1995 confirmed the low concentration of RSCs found there in May 1995.

\subsubsection{Comparison Between the Tropical Industrial Area Of Camaçari in Bahia State And Cubatão in São Paulo State}

Unfortunately, there is a considerable lack of data and research concerning RSC concentrations in tropical industrial areas.

The results, which were obtained in the industrial area of Cubatão, São Paulo using the same methodology, are shown in Table VI.

Obviously, the verified environmental RSC concentrations in Cubatão were considerably higher than those encountered near the Petrochemical Complex of Camaçari in Bahia.

Local RSC atmospheric concentrations seem to depend on the local conditions of wind circulation. The higher concentration levels of RSC in Cubatão were found between sunrise and mid-day when the wind direction changes by $180^{\circ} \mathrm{C}$ (from sea breeze $/ 225^{\circ} \mathrm{C}$ to land breeze $/ 45^{\circ} \mathrm{C}$ ) and, consequently, the 
sampling sites downwind of the industrial emissions receive maximum sulphur gas concentrations.

Locally determined meteorological, topographic and technological conditions may influence RSC concentrations in the various industrial sampling sites.

The area of the PCC in Bahia is quite flat and the usually strong sea breeze is expected to dilute the industrial emissions effectively. Figures 6(a), (b), (c) and (d) show backward trajectories of some stations in this area (Lamarão, Dias d'Ávila, BACELL and Gravatá/Camaçari), provided by the NOAA HYSPLIT MODEL. Once more the figures show the contribution of the Atlantic air masses in the

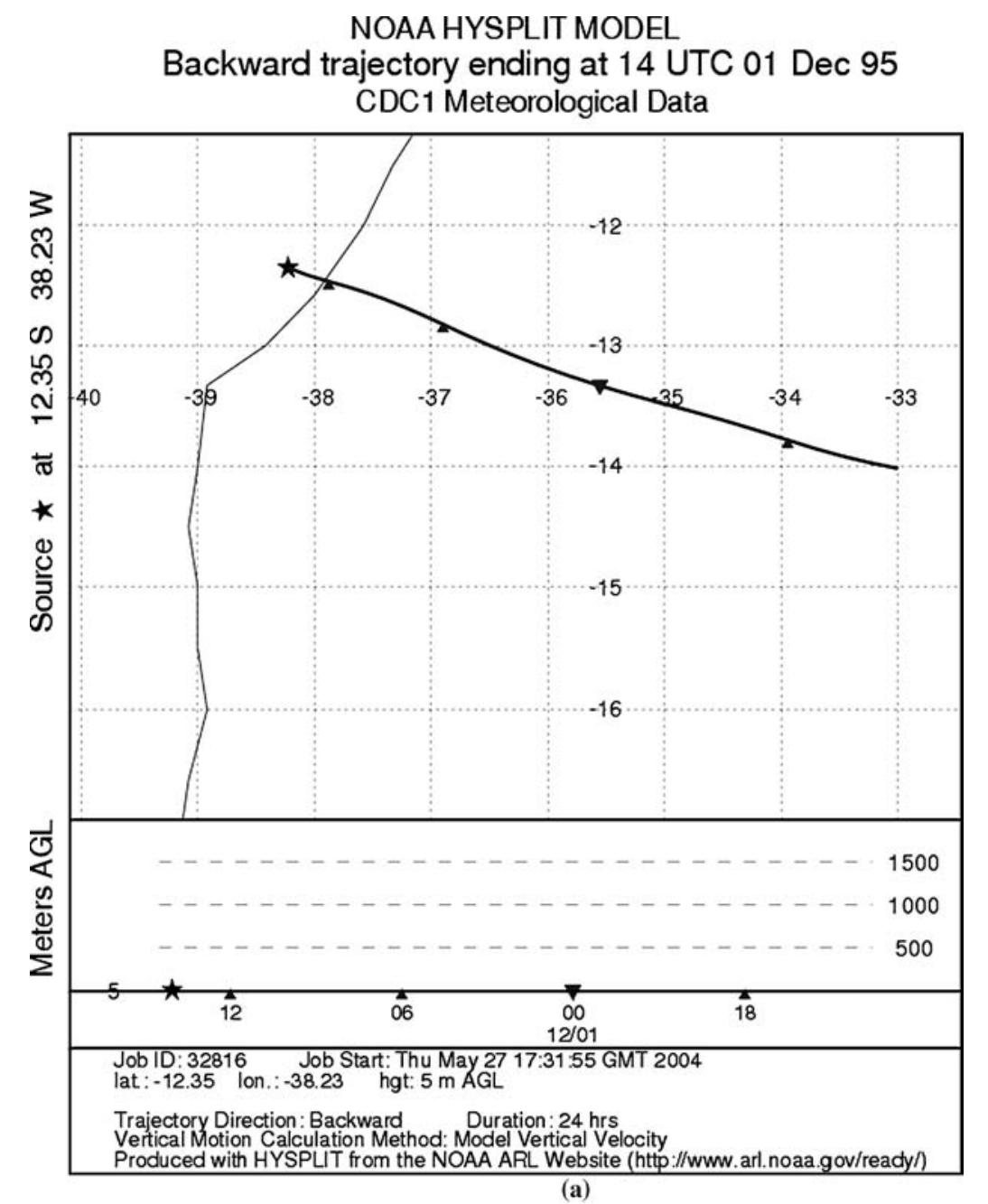

Figure 6. Backward trajectories from some sites submitted to industrial imputs: (a) Lamarão, (b) Dias d'Ávila, (c) BACELL, (d) Gravatá. (Continued on next page). 


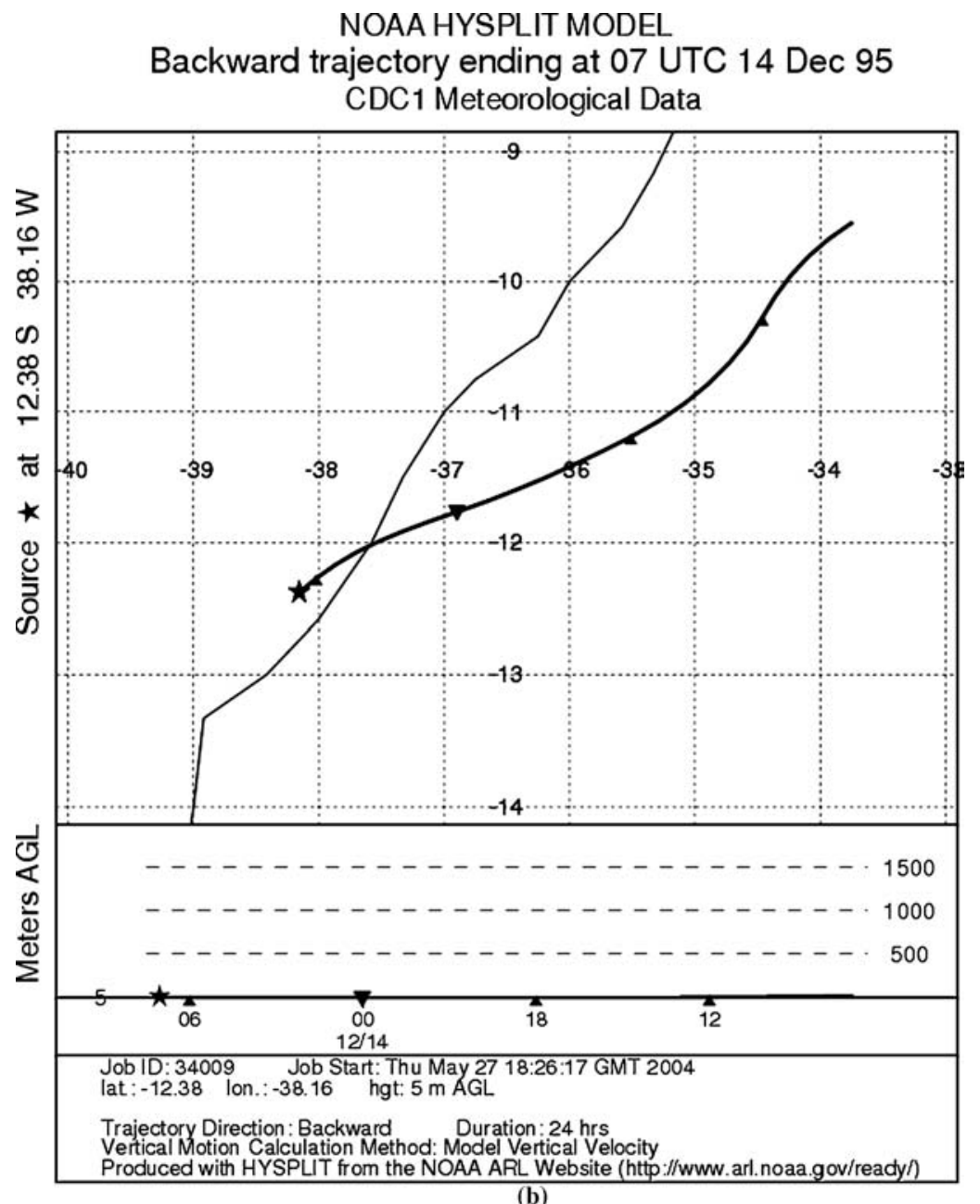

Figure 6. (Continued on next page).

reduction of RSC levels in the industrial area and its vicinity. Nevertheless, inhabitants have complained about a constantly recognizable bad smell attributed to RSCs in residential areas.

In sharp contrast to Camaçari, the city of Cubatão, in the State of São Paulo, is located between the harbour city of Santos (sea level) and the Serra do Mar (up to 800 masl). The topographic rise acts as a barrier against the winds from the Atlantic Ocean. When the sea breeze is weak, industrial emissions tend to accumulate in the atmosphere directly above Cubatão.

In addition, the industrialization process of Cubatão started in 1954 with the foundation of the Petrobras refinery. This industrial plant is not only the predominant emitter in that region, but also operates using rather old and intensively polluting technology. 
NOAA HYSPLIT MODEL

Backward trajectory ending at 06 UTC 06 Dec 95

CDC1 Meteorological Data

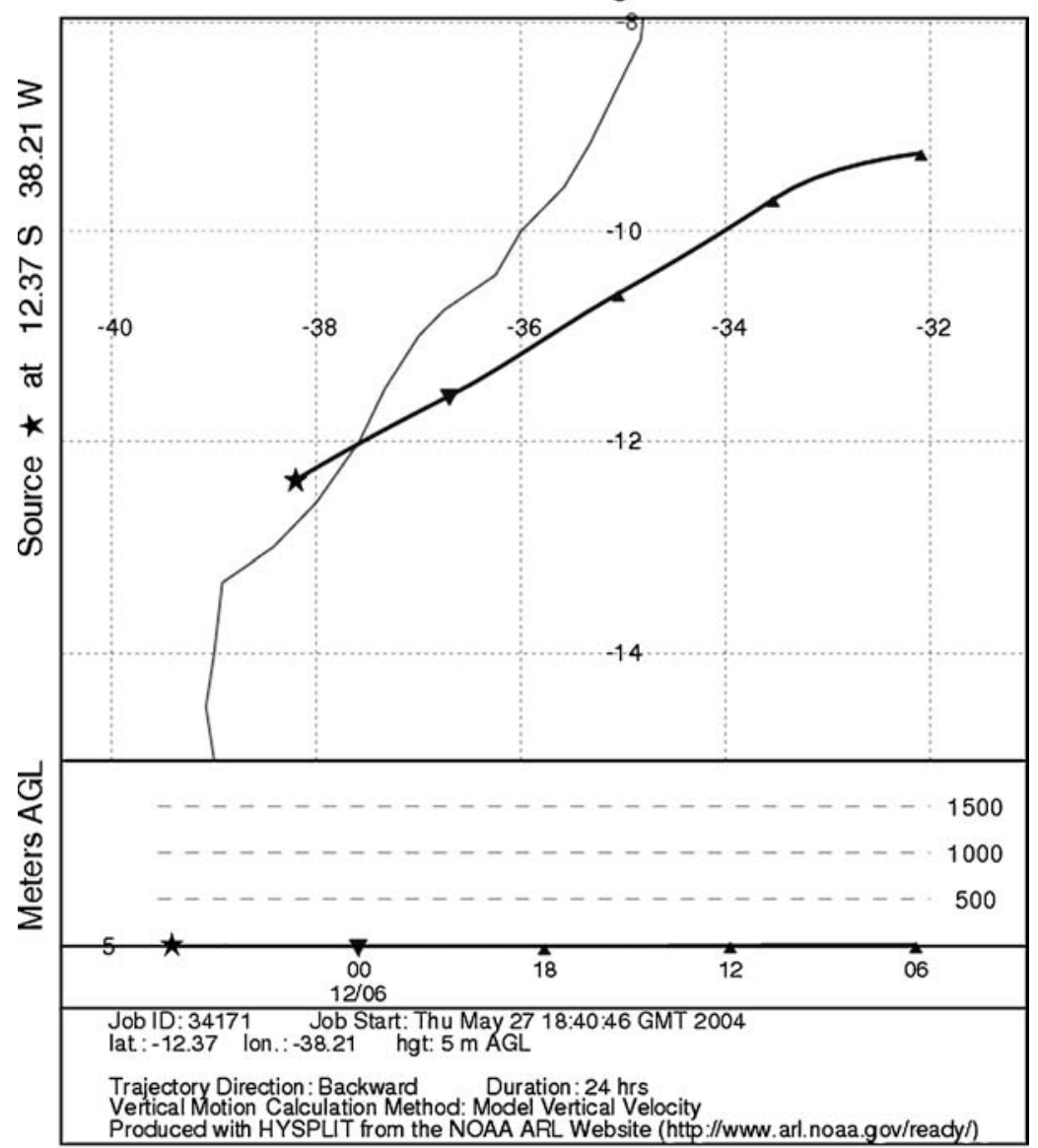

(c)

Figure 6. (Continued on next page).

In contrast to Cubatão, the Petrochemical Complex of Camaçari was erected more recently and is therefore equipped with more modern technology including effective emission control.

\subsection{NATURAL LEVELS}

The environmental concentrations at corresponding sampling locations around the All Saints Bay area are presented in Figure 7, while qualitative results are summarized in Table VII.

All sampling sites showed COS atmospheric concentrations varying between 0.5 and $1.0 \mathrm{ppb}_{\mathrm{v}}\left(23-45 \mathrm{nmol} \mathrm{m}^{-3}\right)$, consistent with their normal global distribution in the atmosphere (Galloway et al., 1995; Berresheim et al. 1995). 
NOAA HYSPLIT MODEL

Backward trajectory ending at 18 UTC 04 Dec 95

CDC1 Meteorological Data

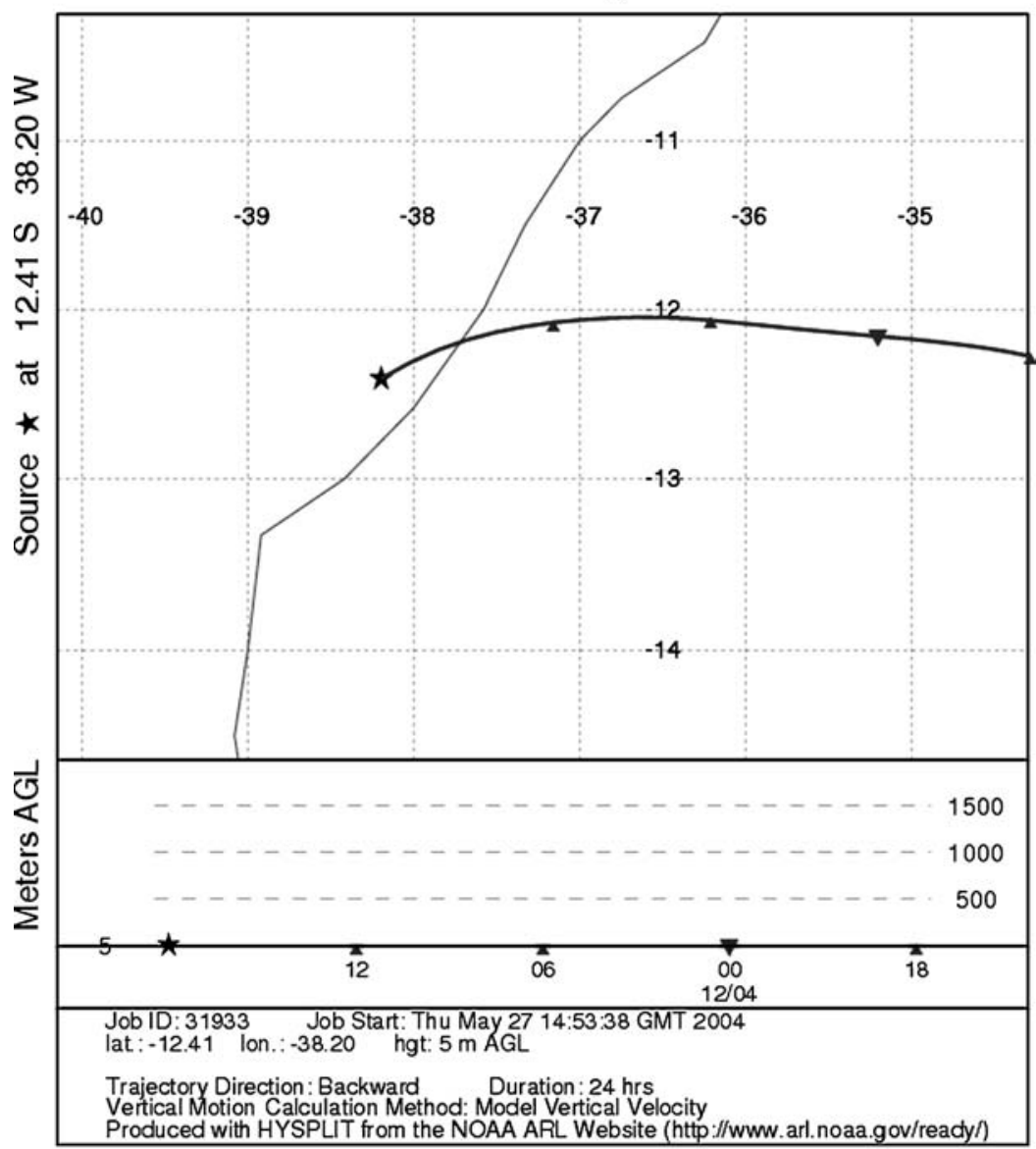

(d)

Figure 6. (Continued).

The anthropogenic emission source of the Landulfo Alves Refinery in Madre de Deus increased the concentrations of COS to $2.0 \mathrm{ppb}_{\mathrm{v}}\left(89 \mathrm{nmol} \mathrm{m}^{-3}\right)$, DMS to $0.55 \mathrm{ppb}_{\mathrm{v}}\left(25 \mathrm{nmol} \mathrm{m}^{-3}\right)$ and $\mathrm{CS}_{2}$ to $0.2 \mathrm{ppb}_{\mathrm{v}}\left(9 \mathrm{nmol} \mathrm{m}^{-3}\right)$. In the areas that were not directly influenced by industrial and urban significant pollutant activities the RSC concentrations were lower than $0.25 \mathrm{ppb}_{\mathrm{v}}\left(11 \mathrm{nmol} \mathrm{m}^{-3}\right)$.

In mangrove areas the $\mathrm{H}_{2} \mathrm{~S}$ concentrations were approximately twice as high ( 0.2 $\mathrm{ppb}_{\mathrm{v}}$ or $11 \mathrm{nmol} \mathrm{m}^{-3}$ ) as those of the Atlantic air masses - a phenomenon accounted for by the process of sulphate reduction in anaerobic systems (Berresheim et al., 1995; Mello, 1994; Jaeschke et al., 1994; Berresheim, 1993). $\mathrm{CH}_{3} \mathrm{SH}$ was not found at many of the sites. 


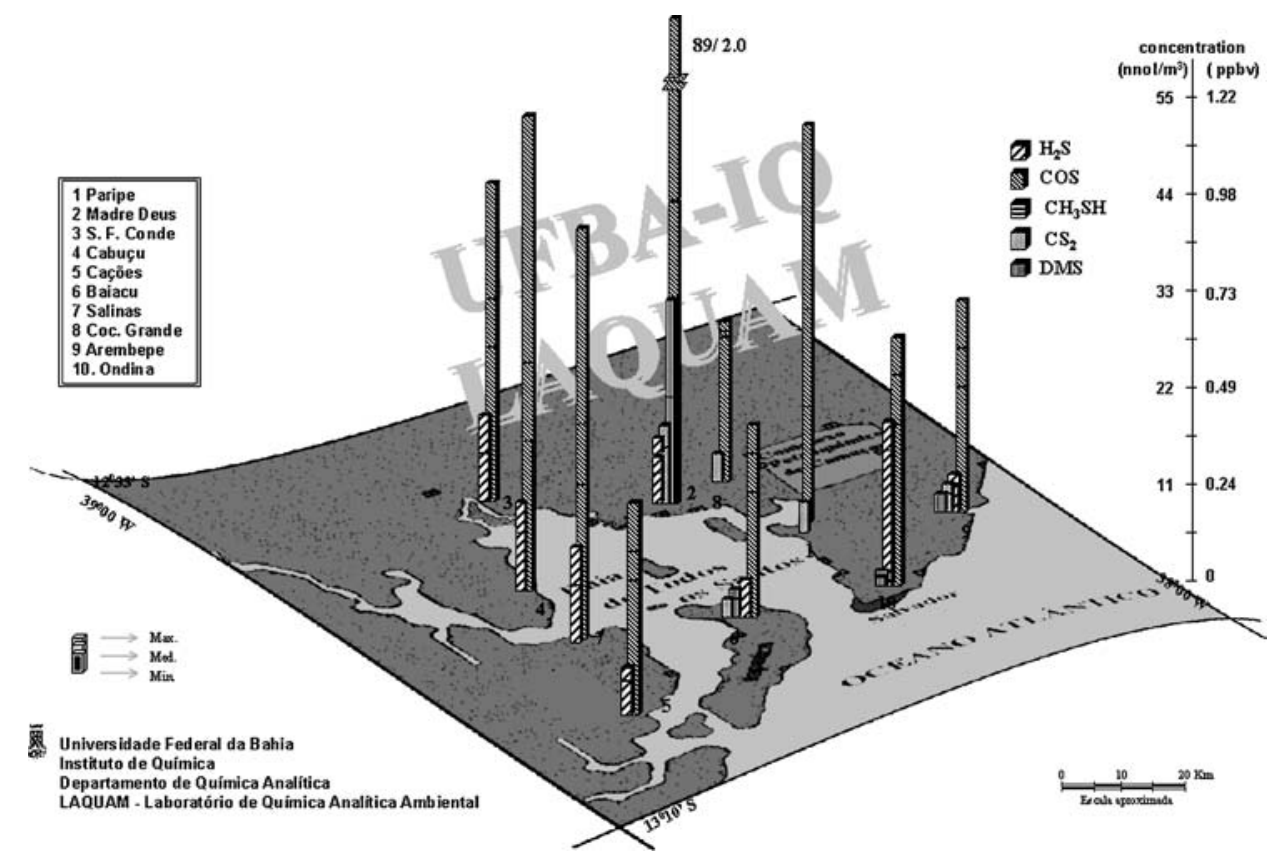

Figure 7. Environmental concentrations of RSCs from biogenic sources around All Saints Bay area, Oct/Nov, 1996.

\subsubsection{Comparison Between the All Saints Bay Area in Bahia State and the Estuary of the Cubatão River in São Paulo State}

Table VIII compares the environmental concentrations of RSCs from Bahia and Sao Paulo states. Dr. Jaeschke's team carried out the measurements in São Paulo using the same methodology (Jaeschke et al., 1994).

The $\mathrm{H}_{2} \mathrm{~S}$ atmospheric concentrations found at the Cubatão River (Jaeschke et al., 1994) are considerably higher than those found in the All Saints Bay area during this study. In comparison with the high $\mathrm{H}_{2} \mathrm{~S}$ atmospheric concentration levels in Cubatão, the low $\mathrm{H}_{2} \mathrm{~S}$ levels observed in the Reconcavo Baiano confirm the importance of wind dilution as well as the absence of any significant topographic barriers in Bahia.

Additionally, the waters of the All Saints Bay area are constantly exposed to regeneration, which contributes to a higher oxygenation of some inland areas, decreasing both the anaerobic stagnation and the production of $\mathrm{H}_{2} \mathrm{~S}$. In contrast the estuary of the Cubatão River is a periodically inundated mud flat. Consequently high $\mathrm{H}_{2} \mathrm{~S}$ concentrations during low tide can be attributed to sulphate reduction in the anoxic sediments of the mud flat.

Apart from the areas submitted to anthropogenic influence, the $\mathrm{CS}_{2}$ and DMS atmospheric concentrations in both Cubatão and All Saints Bay area were recorded below 5.0 and $4.0 \mathrm{nmol} \mathrm{m}^{-3}$, respectively. 
Table VII. RSCs detected in the sampling locations around the All Saints Bay area in 1996

\begin{tabular}{|c|c|c|c|c|c|}
\hline Sampling location & Site characteristics & $\begin{array}{l}\text { Date } \\
(1996)\end{array}$ & $\begin{array}{l}\text { Period } \\
\text { (h) }\end{array}$ & $\begin{array}{l}\text { No. of } \\
\text { Samples }\end{array}$ & RSC detected ${ }^{\mathrm{a}}$ \\
\hline Paripe (1) & Eastern part of the Bay & Oct $/ 25$ & $10-13$ & 05 & $\operatorname{COS}(5), \mathrm{CS}_{2}(1)$ \\
\hline Madre de Deus (2) & Downwind the refinery & Oct $/ 28$ & $12-16$ & 09 & $\begin{array}{c}\mathrm{COS}(9), \mathrm{CS}_{2} \\
(2), \mathrm{H}_{2} \mathrm{~S}(4) \\
\text { DMS (4) }\end{array}$ \\
\hline S. F. do Conde (3) & Mangrove area & Oct $/ 30$ & $13-16$ & 05 & $\begin{array}{l}\operatorname{COS}(5), \mathrm{H}_{2} \mathrm{~S} \\
\text { (4) }\end{array}$ \\
\hline Cabuçu (4) & Mangrove area & Oct $/ 31$ & $14-16$ & 04 & $\begin{array}{l}\mathrm{COS}(4), \mathrm{H}_{2} \mathrm{~S} \\
\text { (3) }\end{array}$ \\
\hline Cações (5) & Mangrove area & Nov/04 & $13-16$ & 04 & $\operatorname{COS}(4), \mathrm{H}_{2} \mathrm{~S}(2)$ \\
\hline Baiacu (6) & Mangrove area & Nov/05 & $13-16$ & 05 & $\begin{array}{c}\mathrm{COS}(5), \mathrm{CS}_{2} \\
(1), \mathrm{H}_{2} \mathrm{~S}(2) \\
\text { DMS (3) }\end{array}$ \\
\hline Salinas (7) & Mangrove area & Nov/06 & $12-15$ & 05 & $\begin{array}{l}\operatorname{COS}(5), \mathrm{H}_{2} \mathrm{~S} \\
\text { (3) }\end{array}$ \\
\hline Coqueiro Grande (8) & Upwind the refinery & Nov/08 & $10-12$ & 05 & $\begin{array}{l}\mathrm{COS}(5), \mathrm{CS}_{2} \\
\text { (1) }\end{array}$ \\
\hline Arembepe (9) & Background coastal site & Nov/13 & 09-13 & 05 & $\begin{array}{c}\mathrm{COS}(5), \mathrm{CS}_{2} \\
(3), \mathrm{H}_{2} \mathrm{~S}(3), \\
\text { DMS (3) }\end{array}$ \\
\hline
\end{tabular}

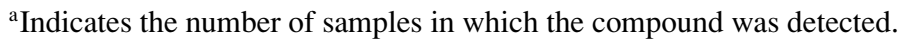

Table VIII. Atmospheric concentrations of RSCs in the All Saints Bay area in Bahia and the estuary of Cubatão River in Sao Paulo

\begin{tabular}{lll}
\hline Compound & $\begin{array}{l}\text { All Saints Bay area (BA) } \\
\left(\mathrm{nmol} \mathrm{m}^{-3}\right)\end{array}$ & $\begin{array}{l}\text { Estuary of the Cubatão River (SP) } \\
\left(\mathrm{nmol} \mathrm{m}^{-3}\right)\end{array}$ \\
\hline $\mathrm{H}_{2} \mathrm{~S}$ & $5-11$ & $15-56$ \\
$\mathrm{COS}$ & $23-45$ & $25-37$ \\
$\mathrm{CS}_{2}$ & $<5$ & $2.7-4.8$ \\
$\mathrm{DMS}$ & $<3$ & 3.7 \\
\hline
\end{tabular}

Levels of COS atmospheric concentrations from natural emissions were consistent with their global distribution $\left(25-40 \mathrm{nmol} \mathrm{m}^{-3}\right)$.

\section{Conclusions}

The low concentrations of reduced sulphur compounds at Arembepe and Praia do Forte confirmed these two locations as suitable background sites. The average atmospheric concentrations found for $\mathrm{H}_{2} \mathrm{~S}, \mathrm{CH}_{3} \mathrm{SH}, \mathrm{CH}_{3} \mathrm{SCH}_{3}$ and $\mathrm{CS} 2$ were below $0.15 \mathrm{ppb}_{\mathrm{v}}$ while COS levels varied between 0.5 and $0.8 \mathrm{ppb}_{\mathrm{v}}$. 
Relatively high levels of the above mentioned reduced sulphur compounds were found in the air of the Petrochemical Complex in Camaçari where four distinctive emission sources could be identified. The highest concentration levels of these compounds were determined in the vicinity of the industries CETREL (COS 8 $\mathrm{ppb}_{\mathrm{v}}, \mathrm{CH}_{3} \mathrm{SH} 1.50 \mathrm{ppb}_{\mathrm{v}}$ and $\left.\mathrm{H}_{2} \mathrm{~S} 1.35 \mathrm{ppb}_{\mathrm{v}}\right)$ and RHODIA $\left(\mathrm{CH}_{3} \mathrm{SH} 1.50 \mathrm{ppb}_{\mathrm{v}}\right)$.

Adverse meteorological conditions during the campaign in Dias d'Ávila and Lamarão do Passé contributed to the dispersion of pollutants at these sites and probably led to lower than expected concentrations of reduced sulphur compounds.

The coastline around the Reconcavo Baiano showed low, but constant concentrations of reduced sulphur compounds with the exception of sites downwind of anthropogenic and industrial sources where higher concentrations were detected: COS $2.0 \mathrm{ppb}_{\mathrm{v}}$, DMS $0.55 \mathrm{ppb}_{\mathrm{v}}$ and $\mathrm{CS}_{2} 0.2 \mathrm{ppb}_{\mathrm{v}}$.

\section{Acknowledgements}

This study was supported by a research grant to W.J. and T.M.T. from the Volkswagenwerk Foundation and by a research grant to T.M.T. for field measurements in Bahia and a scholarship to L.S.S.N. from the National Scientific and Technological Development Council - CNPq of Brazil as well as the Bundesministerium für Forschung und Technologie - BMFT of Germany. The project received considerable encouragement and helpful co-operation from the local residents of the study areas around the All Saints Bay. Backward trajectories using the HYSPLIT MODEL were provided by National Oceanic and Atmospheric Administration (NOOA).

\section{References}

Andreae, M. O. and Jaeschke, W., 1992: Exchange of sulphur between biosphere and atmosphere over temperate and tropical regions, in R. Howard, I. Stewart, M. Ivanow (ed.), Sulphur Cycling on the Continents, Scope, John Wiley and Sons Ltd, pp. 27-61.

Andreae, M. O., Elbert, W. and Mora, S. J., 1995: Biogenic sulfur emissions and aerosols over the tropical South Atlantic: Atmospheric dimethylsulfide, aerosols and cloud condensation nuclei, $J$. Geophys. Res. 100(D6), 11335-11356.

Bates, T. S., Lamb, B. K., Guenther, A., Dignon, J., and Stoiber, R. E., 1992: Sulfur emissions to the atmosphere from natural sources, J. Atmos. Chem. 14, 315-337.

Berresheim, H., 1993: Distribution of atmospheric sulphur species over various wetland regions in the southeastern U.S.A., Atmos. Environ. 27A(2), 211-221.

Berresheim, H. and Jaeschke, W., 1983: The contribution of volcanoes to the atmospheric sulfur budget, J. Geophys. Res. 88 (C6), 3732-3740.

Berresheim, H. and Vulcan, V. D.,1992: Vertical distributions of COS, CS2, DMS and other sulfur compounds in a Loblolly pine forest, Atmos. Environ. 26A, 2031-2036.

Berresheim, H., Wine, P. H. and Davis, D. D., 1995: Sulfur in the atmosphere, in H. B. Singh (ed.), Composition, Chemistry, and Climate of the Atmosphere, U.S.A., Van Nostrand Reinhold, pp. 251-307. 
Charlson, R. J., Lovelock, J. E., Andreae, M. O., Warren, S. G., 1987: Oceanic phytoplankton, atmospheric sulphur, cloud albedo and climate, Nature 326, 655-661.

Cullis, C. F. and Hirschler, M. M., 1980: Atmospheric sulphur: Natural and man-made sources, Atmos. Environ. 14, 1263-1278.

Davison, B. M. and Allen, A. G., 1994: A method for sampling dimethylsulfide in polluted and remote marine atmospheres, Atmos. Environ. 28, 1721-1729.

Davison, B., O’Dowd, C., Hewitt, C. N., Smith, M. H., Harrison, R. M., Peel, D. A., Wolf, E., Mulvaney, R., Schwikowski, M., and Baltensperger, U., 1996: Dimethyl sulfide and its oxidation products in the atmosphere of the Atlantic and southern oceans, Atmos. Environ. 30, 1895-1906.

Dippell, J. and Jaeschke, W., 1996: A Comparison between natural and anthropogenic emissions of the reduced sulfur compounds $\mathrm{H}_{2} \mathrm{~S}, \mathrm{COS}$, and $\mathrm{CS}_{2}$ in a tropical industrialized region, J. Atmos. Chem. 25, 251-270.

Fagá, I., Massaro, S. and Pitombo, L. R. M., 1985: Compostos de enxofre na atmosfera - contribuição de fontes naturais e antropogênicas, Química Nova 162-167.

Galloway, J. N., Charlson, R. J., Andreae, M. O., and Rodhe, H., 1985: The Biogeochemical Cycling of Sulfur and Nitrogen in the Remote Atmosphere, D. Reidel Publishing Company, Dordrecht, The Netherlands.

Haunold, W., Georgii, H. -W. and Ockelmann, G., 1992: Gas chromatographic analysis of atmospheric sulfur dioxide and reduced sulfur compounds, $L C$-GC INTL. 5(10), 28-35.

HSDB(Hazardous Substances Data Bank) 1994: MEDLARS Online Information Retrieval System, National Library of Medicine.

Jaeschke, W., Dippell, J., Sitals, R., and Haunold, W., 1994: Measurements of reduced sulphur compounds in an industrialized tropical region-Cubatao (Brazil), Int. J. Environ. Anal. Chem. 54, 315-337.

Kangas, J., Jäppinen, P., Savolainen, H., 1984: Exposure to hydrogen sulfide, mercaptans and sulfur dioxide in pulp industry, Am. Ind. Hyg. Assoc. J. 45 (12), 787-790.

Marttila, O., Jaakkola, J. J. K., Partti-Pellinen, K., Vilkka, V., and Haahtela, T., 1995: South Karelia air pollution study: Daily symptom intensity in relation to exposure levels of malodorous sulfur compounds from pulp mills, Environ. Res. 71, 122-127.

Matrai, P. A., Balch, W. M., Cooper, D. J., and Saltzman, E. S., 1993: Ocean color and atmospheric dimethyl atmospheric dimethyl sulfide: On their mesoscale variability, J. Geophys. Res. 98 (D12), 23469-23476.

Mello, W. Z., 1994: Como os Seres Vivos Produzem Gases de Enxofre, Ciência Hoje, 17(98), 28-37.

Mihalopoulos, N., Nguyen, B. C., Boissard, C., Campin, J. M., Putaud, J. P., Belviso, S., Barnes, I., and Becker, K. H., 1992: Field study of dimethylsulfide oxidation in the boundary layer: Variations of dimethylsulfide, methanesulfonic acid, sulfur dioxide, non-sea-salt sulfate and aitken nuceoi at a coastal site, J. Atmos. Chem. 14, 459-477.

Nguyen, B. C., Mihalopoulos, N., Putaud, J. P., Gaudry, A., Gallet, L., Keene, W. C., and Galloway, J. N., 1992: Covariations in oceanic dimethyl sulfide, its oxidation products and rain acidity at Amsterdam Island in the southern Indian Ocean, J. Atmos. Chem. 15, 39-53.

Nunes, L. S. S., 1995: Adequação de um Monitor Automático Contínuo de $\mathrm{H}_{2} \mathrm{~S}$ Atmosférico para Regiões Tropicais e Análise de sua Aplicação no Recôncavo Baiano e em Cubatão-SP, Instituto de Química - Universidade Federal da Bahia, Brazil.

Tarrasón, L., Turner, S. and Fløisand, I., 1995: Estimation of seasonal dimethyl sulphide fluxes over the North Atlantic Ocean and their contribution to European pollution levels, J. Geophys. Res. 100 (D6), 11623-11639.

Warneck, P., 1988: Chemistry of the Natural Atmosphere, Academic Press, U.S.A., pp. 484-542. 